\title{
The data and use of bilateral internal thoracic artery grafting: A paradox indeed
}

\author{
Paul Kurlansky, MD
}

See related article on pages $841-7$.

Considerable and convincing retrospective data now support an improved long-term survival with BITA versus single internal thoracic artery (SITA) bypass grafting for patients with multivessel coronary artery disease. ${ }^{1,2}$ Nonetheless, adoption by the surgical community has been remarkably modest, with BITA use less than 5\% in the United States ${ }^{3}$ and only $12 \%$ in Europe. ${ }^{4}$ Even proponents seem to use the technique in less than $20 \%$ of patients. ${ }^{5}$ The reasons for this reluctance are manifold and have been discussed. ${ }^{6}$ One aspect of this resistance arises from the complex nature of the patients we currently care for. BITA grafting may be advantageous for a group of patients, but will it benefit the specific patient on whom I am operating today? It is in just this realm of uncertainty that studies such as that reported by Benedetto and colleagues ${ }^{7}$ in this issue of the Journal become so important.

Efforts to define those patients who derive the most benefit from BITA grafting have been helpful, but they tend to rely on retrospective single-center studies. Diabetic patients $^{8,9}$ and patients with moderately but not severely reduced ejection fraction seem to benefit, ${ }^{10}$ whereas the benefit for women, although theoretically appealing on the basis of the smaller size of their coronary arteries, has been less than impressive, ${ }^{11}$ and that in the elderly controversial at best. ${ }^{12-15}$ It certainly is encouraging that the prospective randomized control Arterial Revascularization Trial was designed to address many of these issues, ${ }^{16}$ and it is further encouraging that the investigators appear to have achieved their enrollment goals. ${ }^{17}$ However, even with this ambitious and sorely needed study, certain issues may be left in the balancein situ versus free grafting and skeletonized versus pedicle grafts. Moreover, we will be left to wonder how many of the surgeons involved really had equipoise and how the

From the Department of Surgery, Columbia University, New York, NY.

Disclosures: Author has nothing to disclose with regard to commercial support.

Received for publication Nov 27, 2014; accepted for publication Nov 28, 2014; available ahead of print Jan 9, 2015

Address for reprints: Paul Kurlansky, MD, Department of Surgery, Columbia University, Black Building 210, 650 West 168th St, New York, NY 10032

(E-mail: pk2245@cumc.columbia.edu).

J Thorac Cardiovasc Surg 2015;149:848-9

$0022-5223 / \$ 36.00$

Copyright (c) 2015 by The American Association for Thoracic Surgery

http://dx.doi.org/10.1016/j.jtcvs.2014.11.084
$72 \%$ of eligible patients who were not randomized might have affected the results. As with most complex issues of therapeutic import, it is ultimately a synthesis of results from well-conceived and conducted prospective and retrospective studies that will be required to yield clinically applicable information.

Therefore, the work of Benedetto and colleagues addressing the issue of BITA grafting in the obese patient is most welcome. Obesity has reached epidemic proportions with more than one third of US adults $(34.9 \%)$ and approximately $17 \%$ (or 12.7 million) of children and adolescents aged 2 to 19 years manifesting obesity. ${ }^{18}$ Given the well-recognized association of obesity with cardiovascular disease and diabetes, ${ }^{19}$ and thus the proclivity for multivessel disease in many of these patients, the role of surgical revascularization assumes increasing importance. The relationship of obesity to cardiac surgical outcomes is complex, with data supporting improved perioperative outcomes in overweight patients fueling the controversy regarding the relevance of the "obesity paradox" to surgical patients. ${ }^{20}$ In regard to the use of BITA grafting, recent data support the contribution of obesity, combined with diabetes and female gender, to the occurrence of deep sternal wound infection in patients undergoing BITA grafting. ${ }^{21,22}$ Indeed, even among matched patients, Benedetto and colleagues ${ }^{7}$ found an approximately triple risk of deep sternal wound infection in the BITA versus SITA groups $(2.6 \%$ vs $0.9 \%)$. The fact that this low-incidence event did not achieve statistical significance in a relatively small cohort of patients may have more to do with statistical limitations of sample size than the pathophysiology of sternal infection. However, the fact remains that within the limitations imposed by the sample size of only 229 patients in each group, the long-term survival benefit was significant. Here again, the relatively horizontal lines achieved in survival curves of the patients undergoing BITA may reflect a limited patient population available for follow-up rather than actual prognosis, yet the difference between the curves in matched patients is compelling. Unfortunately, one parameter of considerable potential relevance that was not well matched between the groups was the number of grafts per patient: $2.88 \pm 0.74$ for BITA and $2.72 \pm 0.82$ for SITA, with a $P$ value of .002 for the difference. Because the groups appeared to be well matched for the extent of disease, it is difficult to separate completeness of revascularization from BITA grafting in the assessment of survival benefit. However, although completeness of revascularization has 
been demonstrated to be a powerful predictor of long-term survival after coronary artery bypass grafting, ${ }^{23}$ the most appropriate mechanism of determination requires a complex assessment of functional and anatomic considerations (eg, ischemic burden, myocardial viability, and fractional flow reserve). ${ }^{24}$ Simply counting distal anastomoses and the number of diseased vessels is less likely to yield meaningful results than has traditionally been surmised.

Despite the limitations that accompany even the most rigorous of retrospective reviews, the contribution of Benedetto and colleagues ${ }^{7}$ gives us increased confidence that the obese patient with multivessel disease, a patient whom we are apt to encounter for the foreseeable future, is more likely than not to derive greater benefit than harm from the use of both internal thoracic arteries as part of a comprehensive strategy of optimal revascularization.

\section{References}

1. Yi G, Shine B, Rehman SM, Altman DG, Taggart DP. Effect of bilateral internal mammary artery grafts on long-term survival: a meta-analysis approach. Circulation. 2014;130:539-45.

2. Weiss AJ, Zhao S, Tian DH, Taggart DP, Yan TD. A meta-analysis comparing bilateral internal mammary artery with left internal mammary artery for coronary artery bypass grafting. Ann Cardiothorac Surg. 2013;2:390-400.

3. Tabata M, Grab JD, Khalpey Z, Edwards FH, O'Brien SM, Cohn LH, et al. Prevalence and variability of internal mammary artery graft use in contemporary multivessel coronary artery bypass graft surgery: analysis of the Society of Thoracic Surgeons National Cardiac Database. Circulation. 2009; 120:935-40.

4. Kappetein AP, Dawkins KD, Mohr FW, Morice MC, Mack MJ, Russell ME, et al. Current percutaneous coronary intervention and coronary artery bypass grafting practices for three-vessel and left main coronary artery disease. Insights from the SYNTAX run-in phase. Eur J Cardiothorac Surg. 2006;29:486-91.

5. Lytle BW, Blackstone EH, Loop FD, Houghtaling PL, Arnold JH, Akhrass P, et al. Two internal thoracic artery grafts are better than one. J Thorac Cardiovasc Surg. 1999;117:855-72.

6. Kurlansky P. Thirty-year experience with bilateral internal thoracic artery grafting: where have we been and where are we going? World J Surg. 2010;34: 646-51.

7. Benedetto U, Montecalvo A, Kattach H, Amrani M, Raja SG. Impact of the second internal mammary artery on short- and long-term outcomes in obese patients: a propensity score matched analysis. J Thorac Cardiovasc Surg. 2015;149:841-7.

8. Puskas JD, Sadiq A, Vassiliades TA, Kilgo PD, Lattouf OM. Bilateral internal thoracic artery grafting is associated with significantly improved long-term survival, even among diabetic patients. Ann Thorac Surg. 2012;94:710-5.
9. Dorman MJ, Kurlansky PA, Traad EA, Galbut DL, Zucker M, Ebra G. Bilateral internal mammary artery grafting enhances survival in diabetic patients: a 30-year follow-up of propensity score-matched cohorts. Circulation. 2012;126: 2935-42.

10. Galbut DL, Kurlansky PA, Traad EA, Dorman MJ, Zucker M, Ebra G. Bilateral internal thoracic artery grafting improves long-term survival in patients with reduced ejection fraction: a propensity-matched study with 30-year follow-up. J Thorac Cardiovasc Surg. 2012;143:844-53.

11. Kurlansky PA, Traad EA, Dorman MJ, Galbut DL, Zucker M, Ebra G. Bilateral internal mammary artery grafting reverses the negative influence of gender on outcomes of coronary artery bypass grafting surgery. Eur J Cardiothorac Surg. 2013;44:54-63.

12. Mohammadi S, Dagenais F, Doyle D, Mathieu P, Baillot R, Charbonneau E, et al Age cut-off for the loss of benefit from bilateral internal thoracic artery grafting. Eur J Cardiothorac Surg. 2008;33:977-82.

13. Medalion B, Mohr R, Frid O, Uretzky G, Nesher N, Paz Y, et al. Should bilateral internal thoracic artery grafting be used in elderly patients undergoing coronary artery bypass grafting? Circulation. 2013;127:2186-93.

14. Benedetto U, Amrani M, Raja SG. Harefield Cardiac Outcomes Research Group. Guidance for the use of bilateral internal thoracic arteries according to survival benefit across age groups. J Thorac Cardiovasc Surg. 2014;148:2706-11.

15. Pettinaria M, Sergeant $P$, Meurisb B. Bilateral internal thoracic artery grafting increases long-term survival in elderly patients. Eur J Cardiothorac Surg. 2014; doi:10.1093/ejcts/ezu206.

16. Taggart DP, Lees B, Gray A, Altman DG, Flather M, Channon K, ART Investigators. Protocol for the Arterial Revascularisation Trial (ART). A randomised trial to compare survival following bilateral versus single internal mammary grafting in coronary revascularization. Trials. 2006;7:7.

17. Taggart DP, Altman DG, Gray AM, Lees B, Nugara F, Yu LM, et al; ART Investigators. Randomized trial to compare bilateral vs. single internal mammary coronary artery bypass grafting: 1-year results of the Arterial Revascularisation Trial (ART). Eur Heart J. 2010;31:2470-81.

18. Overweight and obesity. Available at: http://www.cdc.gov/obesity/data/facts. html. Accessed November 27, 2014.

19. Yatsuya H, Li Y, Hilawe EH, Ota A, Wang C, Chiang C, et al. Global trend in overweight and obesity and its association with cardiovascular disease incidence. Circ J. 2014;78:2807-18.

20. Stamou SC, Nussbaum M, Stiegel RM, Reames MK, Skipper ER, Robicsek F, et al. Effect of body mass index on outcomes after cardiac surgery: is there an obesity paradox? Ann Thorac Surg. 2011;91:42-7.

21. Kieser M, Rose MS, Aluthman U, Montgomer M, Louie T, Belenkie I Toward zero: deep sternal wound infection following 1001 consecutive coronary artery bypass procedures using arterial grafts: Implications for diabetic patients. J Thorac Cardiovasc Surg. 2014;148:1887-95.

22. Raza S, Sabik JF, Masabni K, Ainkaran P, Lytle BW, Blackstone EH. Surgical revascularization techniques that minimize surgical risk and maximize late survival after coronary artery bypass grafting in patients with diabetes mellitus. J Thorac Cardiovasc Surg. 2014;148:1257-66.

23. Omer S, Cornwell LD, Rosengart TK, Kelly RF, Ward HB, Holman WL, et al Completeness of coronary revascularization and survival: impact of age and off-pump surgery. J Thorac Cardiovasc Surg. 2014;148:1307-15.

24. Shannon J, Colombo A. Revascularization in multivessel CAD: a functional approach. Nat Rev Cardiol. 2012;9:243-52. 